\title{
Global control of DNA replication timing by the budding yeast telomere protein Rif1
}

\author{
Laure Lemmens ${ }^{1}$, Stefano Mattarocci ${ }^{1}$, Isabella Marcomini ${ }^{1}$, Tianlai Shi ${ }^{2}$, Cindy Follonier ${ }^{3}$, Massimo Lopes ${ }^{3}$, \\ Nicolas Thomä2, David Shore ${ }^{*}$ \\ From Epigenetics and Chromatin: Interactions and processes \\ Boston, MA, USA. 11-13 March 2013
}

\section{Background}

DNA replication in eukaryotes is initiated from specific chromosomal sites (origins) that fire in a defined, cell type-specific temporal pattern. This replication program appears to be under epigenetic control through mechanisms that are still poorly understood.

\section{Materials and methods}

Studies were done in Saccharomyces cerevisiae (W303 background) using standard genetic and molecular methods. Chromatin immunoprecipitation assays were performed in strains in which genes encoding DNA polymerase 1 or 2 were epitope-tagged at their endogenous loci.

\section{Results}

We showed previously that telomere TG-repeat tract length exerts an epigenetic effect in cis on the activity of nearby subtelomeric replication origins, such that a shortened telomere will replicate earlier [1]. Here we show that deletion of the RIF1 gene, which encodes a telomere-specific Rap1-interacting protein involved in telomere length regulation and telomere "capping" [2-5], also leads to premature replication of two different subtelomeric regions examined. A similar effect of RIF1 deletion on other subtelomeric regions has recently been described [6]. We show here that the effect of RIF1 deletion is epistatic to loss of Tel1 or Mec1 (ATM and ATR kinases), does not affect the intra-S phase checkpoint, and operates through a different pathway than the silencing protein Sir3. Deletion of a normally dormant telomere-proximal replication origin exerts a similar effect on replication timing as does deletion of

${ }^{1}$ NCCR "Frontiers in Genetics" program and Department of Molecular Biology, University of Geneva, Geneva 4, CH-1211, Switzerland Full list of author information is available at the end of the article
RIF1, and these two effects are additive. Strikingly, deletion of RIF1 partially suppresses temperature-sensitive mutations in a number of essential genes that encode regulators of DNA replication initiation, without affecting the levels of the relevant gene products, several of which are present in limiting amounts.

\section{Conclusions}

The budding yeast telomere-binding protein Rif1 is shown here to be a global regulator of DNA replication initiation whose loss leads to precocious replication of subtelomeric domains in the budding yeast. This appears to be a highly conserved function of Rif1, since its homologs have recently been shown to exert related effects in both fission yeast and mammalian cells [7-9]. Experiments will be described aimed at understanding the mechanistic basis of the effect of Rif1 on replication timing.

\section{Author details}

${ }^{1}$ NCCR "Frontiers in Genetics" program and Department of Molecular Biology, University of Geneva, Geneva 4, CH-1211, Switzerland. 'Friedrich Miescher Institute for Biomedical Research, Basel, CH-4058, Switzerland. ${ }^{3}$ Institute of Molecular Cancer Research, University of Zurich, Zurich, CH-8057, Switzerland.

\section{Published: 18 March 2013}

\section{References}

1. Bianchi A, Shore D: Early replication of short telomeres in budding yeast. Cell 2007, 128:1051-1062.

2. Hardy CFJ, Sussel L, Shore D: A RAP1-interacting protein involved in silencing and telomere length regulation. Genes Dev 1992, 6:801-814.

3. Ribeyre C, Shore D: Anticheckpoint pathways at telomeres in yeast. Nature structural \& molecular biology 2012, 19:307-313.

4. Anbalagan S, Bonetti D, Lucchini G, Longhese MP: Rif1 supports the function of the CST complex in yeast telomere capping. PLoS genetics 2011, 7:e1002024.

5. Xue $Y$, Rushton MD, Maringele L: A novel checkpoint and RPA inhibitory pathway regulated by Rif1. PLoS genetics 2011, 7:e1002417.

6. Lian HY, Robertson ED, Hiraga S, Alvino GM, Collingwood D, McCune HJ, Sridhar A, Brewer BJ, Raghuraman MK, Donaldson AD: The effect of Ku on

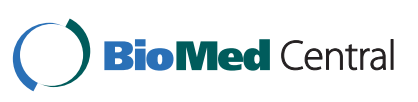


telomere replication time is mediated by telomere length but is independent of histone tail acetylation. Molecular biology of the cell 2011, 22:1753-1765.

7. Yamazaki S, Ishii A, Kanoh Y, Oda M, Nishito Y, Masai H: Rif1 regulates the replication timing domains on the human genome. The EMBO journal 2012, 31:3667-3677.

8. Hayano M, Kanoh Y, Matsumoto S, Renard-Guillet C, Shirahige K, Masai H: Rif1 is a global regulator of timing of replication origin firing in fission yeast. Genes \& development 2012, 26:137-150.

9. Cornacchia D, Dileep V, Quivy JP, Foti R, Tili F, Santarella-Mellwig R, Antony C, Almouzni G, Gilbert DM, Buonomo SB: Mouse Rif1 is a key regulator of the replication-timing programme in mammalian cells. The EMBO journal 2012, 31:3678-3690

doi:10.1186/1756-8935-6-S1-P99

Cite this article as: Lemmens et al:: Global control of DNA replication timing by the budding yeast telomere protein Rif1. Epigenetics \& Chromatin 2013 6(Suppl 1):P99.

\section{Submit your next manuscript to BioMed Central} and take full advantage of:

- Convenient online submission

- Thorough peer review

- No space constraints or color figure charges

- Immediate publication on acceptance

- Inclusion in PubMed, CAS, Scopus and Google Scholar

- Research which is freely available for redistribution

Submit your manuscript at www.biomedcentral.com/submit 